while that of T188A was about three-fold lower. Together with the cofactor-induced conformational changes of the mutants analyzed using $\mathrm{CD}$, we discuss the effects of the substituted amino acids for the structure and function of Ps $3 \alpha H S D$.

\section{P-038リガンドータンパク質間の結合自由エネルギーに対するマルチフ イジクス的計算手法の比較および評価}

Evaluation of multiphysics methodologies for the calculation of ligand-protein binding free energy

Shuntaro Chiba (1), Junma Nomura (1), Yuichi Harano (2), Masahiro Kinoshita (3), Minor Sakurai (1) (1:Center for Biological Resources and Informatics, Tokyo Inst Tech.2:Global Edge Institute, Tokyo Inst Tech.3:Institute of Advanced Energy, Kyoto Univ.)

It is essential to develop the computational method for the binding free energy of ligands to a given protein in aqueous solution because it helps the drug design or the estimation of toxicity chemical compounds. So many computational methods have been developed for these days.

MM_PBSA method is one of the most practical in silico methods developed by Kollman et al. In this method, instead of calculating free energy in solution directly, thermodynamic cycle is considered, which is composed of ligand-binding process in vacuo and a hydration process of each molecule. The former process is calculated with a MM method and the latter is computed with PBSA based on a continuum electrostatics and some empirical rules for nonpolar part of solvation energy.

In this study, we replaced the methods of calculating the binding energy in vacuo and hydration energy by other recently developed methods: fragment molecular orbital theory for the former and/or the theory of morphometric thermodynamics for the latter. In the latter theory, hydration free energy is calculated using four geometric measures and corresponding thermodynamica coefficients. We applied these combined methods to several HIV-1 protease/inhibitor systems. Through the comparison with corresponding experimental data, we are now attempting to find out the best combination of the component theoretical methods.

\section{P-039 時間依存・非依存線形応答理論を用いた誘導適合のメカニズムの} 解明

Induce-fit: revisited by time-dependent and -independent linear response functions applied on perturbed biomolecular systems

Lee-Wei Yang(1), Akio Kitao(1,2) and Nobuhiro Go(3)(1:Univ of Tokyo, Institute of Molecula and Cellular Bioscience; 2:JST, CREST; 3:Japan Atomic Energy Research Institute, Neutron Science Research Center)

Induce-fit (or sequential/KNF) model, explaining ligand-induced conformational changes, is re-comprehended in the context of a linear response theory ${ }^{1}$. Protein conformational changes incurred by perturbations from small ligands, protein docking interfaces or crystal contacts, define the types of biological or pharmaceutical interesting questions to be tackled. The interested degrees-of-freedom in biological system communicate to compile a respons function in answering environmental perturbations. The equilibrium response functions can be generated through a collection of experimentally determined conformers, Elastic Network Model (ENM) or MD/MC simulations. The use of it is demonstrated by predicted configurational transitions between X-ray structures and its NMR-solved conformers. We also derive a time dependent response function from MD simulation of carbonmonoxy myoglobin to track time-dependent conformational changes upon photo-dissociation of $\mathrm{CO}$. The consequently obtained understanding of perturbation propagation is compared with experimental results.[1] Ikeguchi M, Ueno J, Sato M, and Kidera A. (2005) Phys Rev Lett, 94, 078102

\section{P-040 ビーズ•モデルのトレース法の開発と TraceBeads プログラムの作} 成

TraceBeads: a program for tracing beads in bead-ensemble structure

Takashi Nakagawa (1), Yasumasa Morimoto (1), Shigeru Yanagi (1), Kazumoto Kimura (2), Hiroshi Kihara (3), Takamasa Nonaka (4), Masaki Kojima (4) (1:School of Life Sci, Tokyo Univ of Pharm and Life Sciences, 2:Center of Med Informatics, Dokkyo Med Univ Hospital, 3:Dept of Physics, Kansai Med Univ, 4:School of Pharm, Iwate Med Univ)

From small angle X-ray scattering (SAXS) data alone, a low resolution molecular structure can be restored as en ensemble of small beads. In this context, however, each bead is only the constituent unit forming the whole molecular shape, and has no relation with specific atomic groups or residues. In order to determine the internal structure of the bead-ensemble model, we have constructed a new program "TraceBeads" for tracing the polypeptide chain through beads based on the Graph Theory. The program implements the algorithm that explores a "Hamilton-path", assuming individual beads and their neighboring connections as "vertices" and "edges", respectively, to form a "Graph". For the check of the validity of our algorithm, we first used a crystal structure in PDB whose covalent information had artificially been removed to test whether the program could restore the lost information or not. According to the representative point of each residue, we adopted two models, " $\mathrm{C}_{\alpha}$ model" and "centroid model". For ca. 70 differently folded structures selected based on the SCOP classification, only the original main chain could be properly traced without any exception. This result suggested: 1) In spite of a dense packing inside the protein molecule in general, the pathway satisfying the chain compatibility was extremely limited, 2) Once the Hamilton-path was able to be traced successfully, it could be highly expected to be a proper main chain.
2P-041 サルモネラ菌べん毛タイプ || 輸送装置構成蛋白質 FliJの構造

Structure of FliJ, a cytoplasmic component of the flagellar type III protein export apparatus of Salmonella.

Tatsuya Ibuki(1), (2), Masafumi Shimada(1), (2), Tohru Minamino(1), (2), Katsumi Imada(1), (2) and Keiichi Namba(1) (2) (1: Grad Sch of Frontier Biosci. Osaka Univ, 2: Dynamic NanoMachine Project, ICORP, JST)

The flagellum is a motile organelle composed of the basal body rings and the tubular axial structure. The axial component proteins synthesized in the cytoplasm are transferred into the central channel of the flagellum by the flagellar type III protein-export apparatus for self-assembly at the growing end. The apparatus is composed of six transmembrane proteins (FlhA, FlhB, FliO, FliP, FliQ, FliR) and three soluble components (FliH, FliI, FliJ). FliJ is an essential component for protein export. Although FliJ is thought to be a general chaperone, its function is still unclear. Here we report a crystal structure of FliJ. We obtained hexagonal bi-pyramid crystals of FliJ with N-terminal extra three residues, and determined the structure at $2.1-\AA$ resolution using anomalous diffraction data from a mercury derivative collected at SPring-8 BL41XU.

FliJ consists of two $\alpha$-helices, one is a 13-turn helix and the other a 21-turn helix, which form a coiled-coil structure. FliJ has a remarkable structural similarity to the $\gamma$ subunit of F0F1-ATPsynthase. The other soluble components FliH and FliI are also known to have similarity to other components of F0F1-ATPsynthase. The structure of FliI closely resembles those of the $\alpha / \beta$ subunits, and the amino-acid sequence of FliH has two regions that are similar to those of the $b$ and $\delta$ subunits, respectively. We will discuss details of the structure and possible functional mechanism of FliJ, and similarity between the flagellar export apparatus and F0F1-ATPsynthase.

\section{P-042 ビスフェノールAよるカルモジュリンのカルシウムシグナル伝達} 阻害

Calcium signaling inhibition of calmodulin by bisphenol A

Koichi Murayama (1), Tomoyoshi Terada (1) and Sadayuki Matsuda (2). (1: Dept. Biophysics and Physiology, Graduate School of Medicine, Gifu University) (2: School of Natural Science, Engineering and Agriculture, Hokkaido University of Education at Asahikawa

To date, many endocrine disrupters (EDs) are thought to interfere with various biological systems including the reproductive system by mimicking estrogen. Despite many research reports on EDs at various levels from individual to cell, few reports are available for influence on calcium signaling by EDs. For example, exposure of a small amount of bisphenol A (BPA), which is one of the EDs, has influenced to the central nerve and immunity system. Calmodulin $(\mathrm{CaM})$ is a ubiquitous calcium binding protein that plays a key role in numerous cellular calcium-dependent signaling pathways. It is important to molecular biology, physiology as well as environmental sciences to investigate the inhibition of cellular calcium signaling by BPA. Thus, we have examined the inhibition of calcium signaling of CaM by BPA.

Binding of calcium to $\mathrm{CaM}$ and its effects on the complexes of $\mathrm{CaM}$ and bisphenol A were studied by tyrosine excited fluorescence spectroscopy and by circular dichroism spectroscopy. Fluorescence spectroscopy revealed the weakening the calcium binding to $\mathrm{CaM}$ with increasing BPA concentration. $\mathrm{CD}$ spectra also exhibited structural differences of $\mathrm{CaM}$ in the absence and presence of BPA. Here, we will report our results in detail.

2P-043 ミトコンドリア GTPase 蛋白質 Gem1p の生化学的解析

Biochemical analysis of an mitochondrial GTPase, Gem1p

Kai Yasukawa (1), Kenji Kubara (1), Shun-ichiro Kawabata (1), Koji Okamoto (2) and Takumi Koshiba (1)

Mitochondria are dynamic organelles that undergo continual cycles of homotypic fusion and fission, which are believed to play an important role in controlling organelle number, subcellular distribution, morphology, and ATP production. Since mitochondria cannot be generated de novo, transport of mitochondria from the mother cell to its daughter cell is an essential part of cell division. In budding yeast, Gem1p, an outer mitochondrial membrane protein with two GTPase domains and two calcium-binding motifs, acts as a key molecule in mitochondrial inheritance during cell division. In order to investigate the molecular mechanism of the mitochondrial inheritance, we have established a bacterial expression system of recombinant Gemlp. The expression plasmid encoding the recombinant Gem1p was transformed into BL21(DE3) cells, and the gene product was expressed as a soluble form. The recombinant Gem1p showed a proper folded profiles by size exclusion chromatography and dynamic light scattering, and it had potential GDP-binding ability. In this conference, we will more discuss on Gemlp function.

\section{P-044 ヘテロダイマーの多様性：蛋白質複合体構造予測の研究から得ら} れた知見

Structural diversity of hetero-dimers: insights from the study of predicting protein-protein complex structures

Yuko Tsuchiya (1), Eiji Kanamori (2), Haruki Nakamura (3), Kengo Kinoshita (1)

The structural information about protein-protein interactions is critical to understand their functions. A protein-protein docking simulation is one of the approaches to analyze and predict the complex structures. However, there are still several issues to be overcome. Selecting the near-native models from many other models is particularly difficult, due to the structural diversity of the hetero-dimers. Thus, we first classified hetero-dimers and then constructed the optimal scoring 